Please refer to the definitive version of this article when citing:

Hanna, P., Wijesinghe, S., Paliatsos, I., Walker, C., Adams, M., \& Kimbu, A. (2019) Active engagement with nature: outdoor adventure tourism, sustainability and wellbeing. Journal of Sustainable Tourism, https://doi.org/10.1080/09669582.2019.1621883

\title{
Active engagement with nature: outdoor adventure tourism, sustainability and wellbeing
}

\begin{abstract}
:
This article draws on the conflicting arguments surrounding outdoor adventure tourism activities to determine if such activities might usefully be considered beneficial for humans and nature, and how they might offer avenues for sustainable tourism practice. Research in the field has often examined outdoor adventure activities through a lens that either highlights their negative environmental impacts or has sought to conceptualise motivations and/or experiences. In this article we argue that through practices that are often seen as destructive, there is the possibility to think differently about human-nature relationships and pro-environmentalism. To explore these issues, we draw on data collected from a series of semi-structured interviews with outdoor adventure tourists. Our analysis highlights how outdoor adventure tourism facilitates reconnections to nature, offering potential wellbeing impacts and pro-environmental attitudes and behaviours. We conclude that outdoor adventure activities as a form of sustainable tourism have potential implications for our understanding of, and engagement with, sustainability, mental health and wellbeing.
\end{abstract}

\section{Key words:}

Outdoor adventure tourism; Human-Nature relationships; Eco-psychology; Sustainability; Mental Health; Wellbeing

\section{Introduction:}

Over the past fifty years concerns surrounding the impact of humans on the environment have been increasingly voiced (e.g. Goudie, 2019; Mannion, 2014; Nyström, Folke, \& Moberg, 2000). Politically, such concerns have been raised on numerous occasions at a range of international political arenas since the 1980s (e.g. WCED, 1987) and international reports (e.g. IPCC, 2013, 2014). In the academic arena attempts to 'profile' the environmentally conscious individual in terms of demographic characteristics and/or environmental attitudes/beliefs in a range of settings have long been conducted (Barber, 2014; Dolnicar, 2010; Panzone, Hilton, Sale, \& Cohen, 2016). Alternatively, research in the areas of 'sustainable lifestyles' (Cooper, Green, Burningham, Evans, \& Jackson, 2012; Evans \& Jackson, 2007) and 'social practices' (Darnton, Verplanken, White, \& Whitmarsh, 2011; Shove, 2010) have also been prominent in the research arena by attempting to provide a more complex understanding of engagement (or lack of) in pro-environmental practices. However negative human impact on the environment is still increasing through for example: pollution; deforestation; rising sea temperatures; loss of biodiversity; and climate change (Freudenburg \& Muselli, 2013; IPCC, 2014). 
At the same time, contemporary research has persistently pointed to a 'mental health crisis' in which there has been an unprecedented rise in diagnoses of mental health conditions across the world (Gili, Roca, Basu, McKee, \& Stuckler, 2012; Gunnell, Kidger, \& Elvidge, 2018; Thorpe, Florence, \& Joski, 2004; Whiteford et al., 2013) with approximately 1 in 6 people in the UK experiencing a common mental health problem in the past week (McManus, Bebbington, Jenkins, \& Brugha, 2016). Furthermore, there has been an emerging body of literature that suggests that the over pathologisation of mental 'illness' results in an overly medicalised model of mental health (Cromby, Harper, \& Reavey, 2013) and wellbeing which often isolates the individual from many activities that are beneficial to an individual's mental health (Walker, Hart, \& Hanna, 2017). For example, Clift et al. (2010) document the positive impacts that group singing can have on an individual's physical and mental health; Brown, Liu-Ambrose, Tate, and Lord (2009) examined the impact of group exercise on participants wellbeing and concluded that on a number of levels group exercise offered a plausible strategy for coping. Similar results can be found in a range of areas including walking (Johansson, Hartig, \& Staats, 2011), outdoor activities (Adams \& Jordan, 2016), and art (Macpherson, Hart, \& Heaver, 2015), to name but a few. Yet rather interestingly such 'banal' activities often struggle to gain attention as serious health and wellbeing resources (Walker et al., 2017). One such area that appears to be significantly underrepresented in the areas of environmental action and physical and psychological health and wellbeing affects is outdoor adventure tourism.

Much of the research concerning outdoor adventure activities in the leisure context has generally theorised 'nature' as something to 'conquer' or 'overcome' by the participants. For example, Brymer, Downey, and Gray (2009) suggest research tends to focus on the ways participants attempt to conquer the natural space. Other theoretical insights have explored Beck's 'risk theory' (Self, Henry, Findley, \& Reilly, 2007); and 'flow theory' (Stranger, 2010). Similar trends are found in the smaller number of tourism scholars exploring outdoor adventure/sports tourism utilizing 'flow theory', 'reversal theory' and 'edgework' (see Pomfret \& Bramwell, 2014 for a review). Thus Page, Bentley, and Walker (2005) argue that research has been 'preoccupied' with a focus on 'risk', whilst Humberstone (2009) critiques existing research for rarely considering human-nature connections or the embodied and affective relationships that such activities can generate. Rather, such activities often come under scrutiny for being unsustainable due to the impact on often remote and pristine natural environments (e.g. the impact of mountain biking) (Buckley, 2005).

However, there are brief mentions in leisure studies research that active forms of engagement with the environment may facilitate a greater appreciation for nature and subsequent sustainable practices. For example, Brymer et al. (2009) suggest nature-based sports facilitate a deep and ingrained appreciation of nature, something key to sustainable tourism (Hanna, Johnson, Stenner, \& Adams, 2014), and arguably fundamental to efforts for a sustainable society when considering the existent research highlighting the relationship between environmental connectedness and proenvironmental behaviour (Gkargkavouzi, Paraskevopoulos, \& Matsiori, 2018; Klaniecki, Leventon, \& Abson, 2018; Rosa, Profice, \& Collado, 2018). In addition, Thorpe and Rinehart (2010) argue individuals often feel part of their environment, becoming one and the same thing as these environments, whist undertaking such activities. They argue that this could plausibly lead to a greater care for the environment more generally. Yet an empirical investigation has yet to be conducted and thus they call for academics and researchers to further investigate this area, a call this article directly responds to.

Through this research we offer an investigation into re-connecting with nature via outdoor adventure activities within the context of tourism. This article will explore this form of outdoor adventure tourism as a potentially sustainable form of tourism. To do this the article will examine if 
such activities facilitate a greater understanding for and appreciation of nature, and if such activities have the potential to enable positive understandings of mental health and wellbeing. The article will firstly offer an account of the ways in which outdoor adventure activities have been understood and conceptualised. We then turn to eco-psychology and Foucault's ethics (Foucault, 1990), in an attempt to offer an alternative theoretical approach to understanding participation in and understandings of outdoor adventure tourism activities. We then present our findings from a series of interviews with participants of outdoor adventure tourism to examine how they understand their participation through their relationships to nature in terms of the potential relations with the natural environment and their own wellbeing. We conclude that outdoor adventure activities as a form of sustainable tourism have potential implications for our understanding of, and engagement with, sustainability, mental health and wellbeing.

\section{Main body:}

\section{Outdoor adventure tourism}

Outdoor adventure tourism is a complex area lacking a clear definition and often overlapping with adventure leisure and recreation (Williams, 2003). Adventure tourism is divided in 'hard and soft' type of activities, mainly characterised by high or low levels of challenges and risk, uncertainty of outcome and exposure to extreme weather or natural conditions. 'Soft' adventure tourism often includes activities such as walking, trekking or camping, while 'hard' adventure tourism pushes the participant outside of his comfort zone with higher elements of risk and is often associated with activities such as mountain biking, rock climbing, caving, white water rafting, and sky diving to name but a few (Pomfret \& Bramwell, 2014; Shephard \& Evans, 2005; Swarbrooke, Beard, Leckie, \& Pomfret, 2003).

Whilst existing literature in adventure tourism often overlaps with sustainable tourism (Brymer et al., 2009; Dolnicar, 2010; Pomfret \& Bramwell, 2014) such activities have historically generated rather negative perceptions in terms of their impact on the environment. For example, as Olivier (2006) argues, the rise in popularity of risky and dangerous leisure pursuits has led to the question over whether these activities should be regulated or legislated as to the impact it leaves on the environment that adventure tourism relies on. As individuals participating in outdoor adventure activities travel into various natural areas such as national parks and wilderness areas which, are usually difficult to access, Hall (1992) argues that, environmental degradation occurs giving little chance for the environment to recover, having implications for sustainable tourism (Williams \& Soutar, 2005). Relatedly, Wager (1964) suggested, "when too many people use the same area, some traditional wildland values are lost" (Cited in Van Riper, Manning, \& Reigner, 2010).

Several studies have focused on the participants' motives and perceptions of adventure. Risk seeking is arguably the most frequently found participation motive for participating in adventure activities. Brymer et al. (2009) in their study exploring mountaineering adventure travellers, suggested that they are highly motivated to participate in such activities due to the high possibility of outcomes such as injuries or even death. Danger and risk have for a long time been studied as some of the main antecedents of adventure experiences, although they can be either actual or subjective, and perceived as such by the participants (Ewert \& Hollenhorst, 1989). For example in his research on mountain biking, Cessford (1995) argued that the main motives are the need to challenge themselves and expose them to situations characterised by high speed and risk in order to feel excitement and escape from the everyday routine. More contemporary research indicates that other 
psychological needs usually stimulate participation in adventure activities such as insight seeking, self-actualisation, self-fulfilment and social interaction (e.g. Page et al., 2005; Shephard \& Evans, 2005). Other wider classifications of adventure and sustainable tourism motivations include characteristics such as novelty and freedom, boredom avoidance, change of environment, and seeking insight and knowledge about other places and cultures (Bowker \& English, 2002; Buckley, 2012; Tsaur, Lin, \& Liu, 2013).

Further, Palmberg and Kuru (2000) stated that wilderness areas offer rewards which cannot be obtained in the home, urban environment. Ewert and Hollenhorst (1989) and Hall (1992), added that adventure recreationers seek to learn about or reconnect with nature, while Buckley (2012), argued that nature and spirit are also prominent motivators. Studies from the fields of outdoor recreation, tourism and leisure indicate that the participants undertake such activities in order to understand or learn about nature (Pennington-Gray \& Kerstetter, 2002). For example, Goeft and Alder's (2001) study on mountain bikers showed that the mostly preferred rider settings were the trails in mountainous and forested areas because they felt that conservation values and behaviours among the users were higher. Thorpe and Rinehart (2010), drawing from Thrift's (2008) nonrepresentational theory and applying to extreme sports, identify the role of the embodied relationships and practices which happen on time and evoke feelings of connections and spiritual meanings with the natural world, as in relation with gravity and the earth's forces. For example, adventurers "describe themselves as being at one with the natural world or connected through a life enhancing energy" (Brymer et al., 2009, p. 193). Finally, Csikszentmihalyi and Csikszentmihalyi (1992) added that the participants develop emotions of supernaturalism and transcendentalism, as they get fully absorbed by the activity and feel attached to that. However, as Humberstone (2013) stated, there is little research evidence exploring the potential links between outdoor adventure activities and pro-environmental behaviours.

In summary this section highlights the potential that outdoor adventure activities have in facilitating a deep appreciation of, and reconnection with, the natural environment. Further, research has also shown that participating in outdoor adventure tourism activities has the potential to offer therapeutic effects such as rejuvenation (Klaus \& Maklan, 2011). It is in light of the potential of outdoor adventure tourism to offer therapeutic effects that our attention now turns to the concept of wellbeing to offer an account of how this article draws on existing theory to conceptualise wellbeing in the context of this research.

\section{Wellbeing}

In recent years the concept of wellbeing has received increasing attention internationally. Along with physical health, wellbeing constitutes Goal 3 of the United Nations Sustainable Development Goals (UN, 2019) with wellbeing argued to be an essential measure in assessing a nations prosperity (OECD, 2019). Tourism has not let the 'wellbeing agenda' slip its attention and there has been a keen interest in wellbeing over the past decade amongst tourism researchers. Indeed, tourism scholars in the USA, Australia, the Netherlands, the UK and other regions have embraced 'positive psychology' as a theoretical basis to explore the wellbeing effects of the touristic experience. In this research, wellbeing is often understood as 'subjective wellbeing' which generally focuses on the more positive aspects of human existence often employing a specific focus on 'happiness' (e.g. Filep, 2012; McCabe, 2009; McCabe \& Johnson, 2013; Pearce \& Packer, 2013; Petrick \& Huether, 2013). Other research in tourism has focused on wellbeing in relation to later-life (Morgan, Pritchard, \& Sedgley, 2015) and quality of life (Dolnicar, Yanamandram, \& Cliff, 2012); here wellbeing is not understood as 
'happiness' per se but rather something that represents an improvement in a psychological state. Finally, in their paper Morgan et al. (2015) critique the notion of tourism as a facilitator of an improved psychological/wellbeing state by highlighting the complex mixed emotions experienced by mothers holidaying with children diagnosed with developmental difficulties (Sedgley, Pritchard, Morgan, \& Hanna, 2017).

Whist it is not the purpose of this article to present a theoretical argument as to what 'wellbeing' is, it is appropriate to give the reader an understanding of the ways in which we have conceptualised wellbeing in this research. Here we see the benefits of the existent research which has focused on wellbeing as something of a proxy for 'happiness' (e.g. McCabe \& Johnson, 2013), whilst appreciating that wellbeing can also be understood as something more akin to an alleviation of distress (Cromby et al., 2013). Further, in this article we understand wellbeing not as a fixed state, but draw on a more nuanced understanding of wellbeing that functions at the intra- and intersubjective levels functioning through interactions and relationships with other humans and nonhumans (e.g. physical space, the environment, other species) (Walker et al., 2017). To offer a more comprehensive account of our understanding of wellbeing in this context, attention now turns to eco-psychology (Roszak, 1992) to explore the theoretical proposition that outdoor adventure tourism activities could lead to environmental responsibility and improvements in psychological wellbeing.

\section{Eco-psychology and human nature relations}

'There is a deeply bonded and reciprocal communion between humans and nature. The denial of this bond is a source of suffering for both for the physical environment and for the human psyche, and the realization of the connection between humans and nature is healing for both' (Davis, 1998, p. 75)

Since the onset of industrialisation humans have increasingly separated themselves from nature. With the onset of capitalism and the increasing desirability for material objects, nature is featuring less in many people's lives (Louv, 2005). The urban environment has been championed by governments and industry across the planet to facilitate increased production and consumption. Yet as this quote from Davis suggests, it appears we could be putting our physical and mental wellbeing at risk. Eco-psychology has long suggested an 'ecological unconscious' which can be understood as 'assuming a deep, abiding connection between psyche and Gaia' (Roszak, 1995, p. 17). Here we see not the individual of modern psychology in which the unconscious is located within the self, or even within the social, but rather the intra -relationship between the human psyche and the natural world. Of course, in calling it the 'natural world' we are recreating a false and arguably problematic distinction between humans and nature; we are after all part of nature. It is through this distinction that contemporary living for many has severed what Roszak $(1995$, p. 5) argues to be the rooted link where 'at the deepest level the psyche remains sympathetically bonded to the earth that mothered us into existence', with negative implications for psychological wellbeing.

Whilst this might sound like idealistic environmentalism there is compelling evidence regarding this unconscious and intrinsic link between people and the natural environment. For example, Ulrich (1984) sought to explore the effects of nature on bed-bound surgical patients. The research was concerned with the view through the recovery room offered to the bed-bound patients, for some they could see trees from the windows, for others they could see the bricks of an opposing building. Beyond this the room layout, nurses and window position and frame were identical. The results of 
this experiment showed that patients with a view of trees, as opposed to bricks, recovered quicker, took fewer analgesic drugs, and had fewer negative evaluations on condition and recovery in the nurses' notes. Similar positive wellbeing effects of nature have been found in studies exploring simulated nature (Bringslimark, Hartig, \& Patil, 2009); horticultural therapy for schizophrenia (Roberts \& Bradley, 2011); experiencing outdoor green spaces (Barton, Hine, \& Pretty, 2009); engaging with wilderness (Greenway, 1995); and the effects of indoor vegetation on work morale and productivity (Han, 2009).

Furthermore, eco-psychology and environmental education research continue to build evidence of the links between a child's active engagement in outdoor activities and environmental responsibility and attitudes (Palmberg \& Kuru, 2000), including a recent Sustainable Lifestyles Research Group project (Abbas et al., 2013). Nevertheless, this remains to be expanded to adults engaging with outdoor adventure activities in the leisure context, despite constituting a significant and increasing area (Beedie \& Hudson, 2003; Buckley, 2002; Gyimóthya \& Mykletunb, 2004; Hay, 2013; Pomfret \& Bramwell, 2014), with a reconnection to nature central to the experience. Thus it would appear that a focus on the effects of outdoor adventure activities on an individual's understanding of sustainability and the potentially beneficial impact on their psychological wellbeing goes some way to addressing:

'those activities that aim more directly at recalling how our human psyches are embedded in and nurtured by the larger psyche of nature and at relearning the essentially human art of revering, giving back to, and maintaining reciprocal relations with an animate natural world' (Fisher, 2002, p. 13)

Therefore, it is from this point that this article departs. Finding the basis of its theoretical orientation in eco-psychology (Roszak, 1992), and human nature connections (Latour, 2004; Whatmore, 2002), this article draws on the growing theoretical and empirical evidence which suggests that a [re]connection with nature is fundamental in fostering pro-environmental behaviours (Davis, Green, \& Reed, 2009; Gosling \& Williams, 2010; McPherson Frantz \& Mayer, 2014; Nisbet, Zelenski, \& Murphy, 2009) and enhanced psychological wellbeing (Capaldi, Passmore, Nisbet, Zelenski, \& Dopko, 2015; Martyn \& Brymer, 2016; Russell et al., 2013; Zelenski \& Nisbet, 2014; Zhang, Howell, \& Iyer, 2014 ) thus offering further insights into sustainable tourism theory and practice. Finally, what follows in the methodology will further develop the use of Michel Foucault's 'technologies of the self' (Foucault, 1988) to help understand the complexities of ethical subjectivity, sustainable behaviours, and mental health and wellbeing (Hanna et al., 2014).

\section{Methodology}

This research draws on a qualitative methodology which was concerned with the ways in which individuals experience their engagement with outdoor adventure tourism activities and how we might understand this experience in relation to their understanding of the environment, and their psychological wellbeing. At the methodological level, this was achieved by drawing on principles from Foucault's understanding of 'technologies of the self' as applied to contemporary issues (Heyes, 2007). Such principles enabled this research to focus on issues concerning structure and agency, whilst also allowing for an appreciation of meaning, power, subjectivity, affect, embodiment, and experience. This grounding allows this article to explore the ways in which participants were immersed in nature; how they formed relationships to natural spaces; if they experienced a reconnection with nature; if there were affective bonds formed between their psyche 
and the natural environment during their touristic experience; and the ways in which these elements shaped the individuals' thoughts and feelings. The methodological decision to adopt Foucault's 'technologies of the self' was made as it enabled a deeper understanding and investigation of the data to capture some of the complexities of active human nature relationships and more broader 'ethical subjectivities', arguably key to understanding links between nature, eco-psychology and the individual (Hanna et al., 2014).

To explore these issues with a relevant sample we recruited people through the non-probability sampling techniques of convenience sampling and snowball sampling (Bryman, 2004). Members of the research team had contacts who had engaged with outdoor adventure tourism and thus these individuals were the initial participants through which subsequent contacts were recruited to the project. In total a sample of 21 individuals from a variety of outdoor adventure tourism activities ${ }^{1}$, and a range of age and nationalities was obtained (see Table 1). Due to the depth we sought in terms of the participant's experience, this sample size was deemed sufficient. We utilised the wellestablished interview technique of semi-structured interviews to enable us to offer structure in terms of covering key prompts regarding the participants experience (e.g. what they did, how they felt, key moments of the experiences, how they felt the experience has affected their everyday lives); whilst also allowing the participant to create their own narrative over their experiences. Data was collected over a four-month period with interviews lasting 30-90 mins.

The interviews were then transcribed and analysed through multiple readings to fully immerse us in the data and the participants' stories (Smith \& Osborn, 2008). To analyse the data we adopted a theoretically informed version of thematic analysis (Braun \& Clarke, 2006). To do this three members of the research team immersed themselves in the data to get an established 'feel' for each participant's story. The data was then coded in line with the principles of thematic analysis (Braun \& Clarke, 2006). Further, close attention was paid to the four components Foucault argued enables individuals to 'cultivate the self as an ethical subject' as these offer an understanding of the reciprocal relationships (Foucault, 1988, 1990). Further, attention to these components has been suggested to be a useful way of reading data which explores human-nature relationships (Hanna, 2013). The four components are: 1 . What aspects of the self do these individuals identify as a component they are trying to problematize/work on (ethical substance)?; 2 . Why do individuals feel they need to work on this aspect of the self (mode of subjection)?; 3 . What are the practices and attitudes that enable the individual to work on the substance identified and resist/disrupt/unsettle broader constructions and subjectivities (forms of elaboration)?; 4. What is the overarching goal they are working towards (ethical telos)?

In summary the approach adopted enabled the analysis to:

...to identify the manner in which people actively relate to themselves as beings with certain identities, and to their environment; the ways they are incited to constitute themselves as beings with certain rights, responsibilities, obligation, needs, and so on; how they act upon themselves and shape their own lives and their own conduct; and the rationalities according to which they do so (Yates \& Hiles, 2010, p. 66).

Following the analysis by the three team members, all members met to discuss the three independent readings of the data and agree a consensus as to what was emerging from of the data. As the method of analysis was focused on identifying aspects from the four-fold model, and our

\footnotetext{
${ }^{1}$ Including: Mountain biking, Sky diving, Reef diving, Jungle trekking, Hiking, Skiing, Parasailing, Rock climbing; Mountaineering
} 
central research concerns lay in the human-nature relationship, wellbeing, and pro-environmental behaviour, there was a general consistency in the emergent core findings. Thus, what follows is an account of the agreed findings organised through Foucault's four-fold model. Whilst all four elements were utilised in the analysis, the research team agreed that the core focus for this article should be on the attitudes, thoughts, feelings and practices (forms of elaboration) as they relate to human-environment relationships and the impact on conservation and wellbeing.

\section{Findings}

Throughout our data there was a rich body of material covering the complex multiplicity of participation in outdoor adventure activities. For example, whilst some individuals identified fitness as their ethical substance (e.g. "The challenge and also physical fitness...I am 45 years old and can stay fit, with my goal to keep riding until I am 70" P 4), for others the element of the self they were working on appeared more concerned with escaping their everyday self (e.g. "It's a sense of escapism, getting out of the city and the lifestyle of the city too, you know, stress, panic fast pace, urban surroundings around you, traffic, all that stuff" P 2). Further, the reasons for their engagement, the mode of subjection, could be understood through a range of elements at the individual level such as the excitement/thrill (e.g. "I like the excitement, similar to other adventure sports, I like the rush...its interesting and exciting" P 9); the more social elements of the experience (e.g. "hanging out with the guys, we all eat and drink together in the evenings...it's a matter of resocialising after a year of work" P 10); or broader understandings inspired my family upbringing and bonds (e.g. "Since I was little I was always around the sea, so I have this love towards the sea and marine life" $P$ 3).

Therefore, to present our core findings as they relate to existing literature and particularly our focus on environmental practices (forms of elaboration) and individual mental health/wellbeing, the analysis is split into three sections. In the first section, we explore the notion of 'battling' nature and offer an account of the ways in which our participants drew on, and resisted, this notion of outdoor adventure tourism activities. Attention then turns to the affective and immersive experiences the participants had with nature, as is understood through an eco-psychology lens, to explore the potential impacts and benefit such experiences had on their mental health/wellbeing. Finally, our analysis presents an account of the ways our participants felt their engagement with outdoor adventure tourism activities had an impact on their appreciation for, and conservation efforts towards, the environment.

\section{Force of nature}

Through the literature review above, it was demonstrated that in terms of research concerning the motivations for individuals to engage with outdoor adventure activities, much of the research has suggested a desire to 'conquer' or 'overcome' the natural environment (Buckley, 2006). Such understandings were utilised by the participants in this study when they were describing their experience. For example, as one participant comments:

You understand that nature has control, so sometimes I feel like I'm battling against it when the conditions are hard... when you manage to accomplish the task...it feels like an accomplishment but also this is when you realise natures power and control (P 2) 
In this account the participant understands his relationship with nature in a manner akin to the Cartesian dualism between mind and body, but here the mind and body are collapsed to the self, with nature understood as the binary. Such understanding of human-nature relationships are symbolic of contemporary western thought and arguably have been since the $19^{\text {th }}$ century (Pratt, 2007). This binary enables the participant to understand their experience through a heroic discourse in which they go to battle with nature, a nature that "has control" particularly when "conditions are hard". This understanding positions the participant as not only separate from nature, but also enables a position in which they have a specific task to overcome "nature's power and control". Such an understanding echoes findings from studies undertaken by (Palmer, 2004) and Brymer and Gray (2009), who concluded that the adventurers seek do battle against the natural environment in order to prove to themselves their strengths, limits and abilities. Reference to the feeling of an 'accomplishment' in this above extract clearly demonstrates the parallels in understandings.

Similar understandings were found throughout the data corpus, for example as participant 21 comments:

When you find yourself in a different environment, for example, when I am walking and I see a hill, I get related to it immediately because I know the way I am going to tackle it and get to the top. So it helps you realise the environment in a different way depending on where you have been and what you have done ( $P$ 21)

Here the activity of walking is understood through the human-nature split in which the natural environment presents a particular challenge that needs "tackling" by getting to the "top of the hill". Thus, here we see a series of practices and attitudes, or forms of elaboration, through which the individual enacts their engagement with nature (Foucault, 1988, 1990). However, once again then we see how the participants understand their experience with the natural surroundings in a way that presents 'nature' as something to 'conquer' or 'overcome' (Brymer et al., 2009), an attitude seemingly at odds with Foucault's (1990) system of 'reciprocal obligations' which lies at the heart of a 'care of the self'. Thus we could suggest that the we can understand individuals that engage in outdoor adventure activities as individuals that seek risk, danger and the power of nature to explore the boundaries of oneself and takes it as a challenge to overcome the conditions (Buckley, 2006; Swarbrooke et al., 2003). Indeed, through such understandings it could be suggested that far from an unconscious connection to nature (Fisher, 2002), the participants in this research were severing such a connection for their own sense of self-efficacy and fulfilment (Shephard \& Evans, 2005). This severing of the connection from an eco-psychology perspective could be understood as extremely environmentally unproductive, further splitting humans from nature and potentially resulting in a position in which the drive to overcome nature potentially results in a lack of care for the environment as it is the perceived threat (Louv, 2005).

However, in our data this was not the case, whilst our participants partially understood their experience through the dominant discourses of a human-nature split, and as nature as something to battle against and overcome for individual excitement, achievement and pleasure, their understandings were far more nuanced. For example:

The natural environment is something that cannot leave you unaffected. You see mountains, rivers and lakes. You hear the birds or the animals, you smell the air and the ground and sometimes you also develop instincts of behaviour; you know, like wild animals. Although 
sometimes you have to battle with the environmental conditions, trying to overcome the difficulties, overall it is a learning experience ( $P$ 11)

In this extract we once again see the human-nature split as central to the participants understanding, with the "natural environment" explicitly constructed as something separate from the self that "cannot leave you unaffected". Further, we see once again the rhetoric of battling with the other, then environment, as central to the understanding presented. However, we also see the fusing of the participant and their natural environment though the sensory experiences of nature entering the body though the sounds and smells. Additionally, the entering of nature to the embodied human shifts the understanding as something separate from nature, to something that is intrinsically part of nature with "instincts" akin to that of a "wild animal". Such an understanding resonates with Thorpe and Reinhart's (2010) adoption of non-representational theory (Thrift, 2008) which highlighted the embodied relationships and practices which evoked feelings of connection and spiritual meaning with the natural world. Here too we could also see the participants account through the way they "describe themselves as being at one with the natural world or connected through a life enhancing energy" (Brymer et al., 2009, p. 193). Therefore, whilst the dominant understanding of humans and nature are present in the account, we see a far more reciprocal understanding in which the outdoor adventure activities offer the possibility for a 'return to the natural' and a more sustainable understanding of their tourism activities.

The above accounts have highlighted the ways in which the dominant discourse of human versus nature in understandings of outdoor adventure activities operates implicitly through our participants' understandings. However the following extract demonstrated how one participant was aware of this dominant understanding and actively resisted the discursive formation through what could be understood as Foucault's 'technologies of the self' in which active self-reflection on the ways we are invited to understand ourselves is crucial to the 'cultivation of the self as an ethical subject' (Foucault, 1990).

I am more in tune with the environment...I developed a huge sense of respect, nature is not the enemy or something you can control... it gives me the respect and it is up to me how to negotiate, I am not going to conquer it in any way ( $P$ 10)

\section{Immersive environments}

Such is the case that engagement with outdoor adventure activities was not understood simply as a space for overcoming nature, what follows will build on the ways in which the practices associated with outdoor adventure activities enables a rethinking of human-nature relationships through the affective and immersive experiences with nature. Building on from Thorpe and Reinhart's (2010) exploration of the interaction with the natural environment creating images, meanings and narratives captured in emotions of embodiment through outdoor adventure tourism activities, the following extract demonstrates an account of the ways in which participants in this research experienced immersive environments.

I was sleeping outside in a tent and I was hearing sounds around me, dogs or wolves barking, I felt like an animal species, its $3 a m$ and you listen to animals or feel them coming to you. It might be uncomfortable but when you finish the trip you feel stronger, that you survived. You are in the house of nature, including wild animals ( $P$ 7) 
In the above extract the participant explains their experience not as an individual separate to the natural environment, but rather as someone entirely immersed in nature in a reciprocal manner. In a similar light to Csikszentmihalyi and Csikszentmihalyi's (1992) ideas of flow, we can understand this participant's interaction or connection with the natural environment as a way in which they develop emotions of supernaturalism. Through the feeling they have become "like an animal species" the participant appears to shift their understanding from being a human surrounded by nature, to one in which "nature as it is experienced is an animated being, and as such, one enters into the atmosphere of vibrant surroundings" (Lund, 2013, p. 156), arguably becoming part of nature and experiencing the fusion of the human-nature dichotomy. This realisation of being situated within nature directly answers Foucault's concern in the cultivation of the self as an ethical subject regarding the reflection and recognition of ones position in the broader cosmos (Hanna, 2013).

To further develop this, the way in which the participant presents an account is being "in the house of nature" which facilities feeling "stronger" can also be understood through an account that recognised the potential for an unconscious and "deeply bonded and reciprocal communion". This is said to be essential if we are to avoid the psychological pain and suffering for the human, and the physical suffering for the environment, which is argued to be a direct result of the disconnection between humans and nature (Fisher, 2002; Roszak, 1992). Such a re-establishing of this communion is said to be fundamentally healing for both the natural space and the individual psyche (Davis, 1998). In a similar light another participant comments:

I hear sounds, I feel the wind or the ground's forces, I observe animals and natural phenomena like small avalanches happening at a safe distance from me. So all of those things make me think more about Mother Nature and also about the general problems of the earth (P 8)

In this extract the participant understands their experiences through an embodied and sensual experience with nature. This relationship with the environment is one that we could understand through what Latour (2004) calls an 'amodern' or 'post-natural' constitution. In referring to a 'postnatural' constitution, Latour understands the relationship between humans and the environment as one in which the traditional dichotomy is broken down and replaced by a relationality in which both humans and nature are positioned within an agentic network, both acting on and reacting to each other. It is through the practices of smelling, hearing, seeing and feeling that this participant is able to immerse her/himself in this relationship and allow a closeness and connection to the environment that might not otherwise be realised to this extent. Drawing on Anderson (2009, p. 124) we can understand this process as a relational sensibility, in which:

The coming together of non-human, human, embodied practice, and place results in an emotional experience that is both the product of this convergence, and itself becomes part of the broader, relational constitution

These reciprocal relationships appear affective and embodied in their foundations, they represent a place in which the individual can understand the self through a 'genuine' relationship with nature and understanding of their position within the broader eco-system (Quastel, 2008). In this light, the "affective reciprocity and reciprocal dependence" (Foucault, 1990, p. 80) between the individual and the 'other' is central to the experience. Such relationships also enable a reflection on the "general problems of the earth" and also a care for "Mother Nature" which encourages the "connection between psyche and Gaia' (Roszak, 1995) offering benefits to both the participants wellbeing and also potentially their environmental reflections/practices. 
Whilst it was not the aim of this research to quantify the individual wellbeing effects of engagement with outdoor adventure activities, the following quote further develops the case made so far in this section that a reconnection to nature has the potential to be beneficial to the individual's wellbeing. As the following participant notes:

You think you're fine and then in a few seconds you forget everything. You're like a zombie looking at the world but you forget everything. I forgot my fear, I forgot everything so it was really nice $(P 1)$

It is here that the participant recounts their experience not as a reconnection to nature per se, but rather it is through the connection that this individual is able to 'escape the self' (Foucault, 1988). Through the "forgetting" and "zombie" like trance, the natural environment appears to consume the individual and enable a transcendence from their everyday stressors and immediate fears. Such transcendence and 'escape from the self' are often seen as key elements to facilitating alternative mental health interventions and wellbeing enhancement in unconventional spaces (Walker et al., 2017). Everyday worries and anxieties, symbolic of the 'mental health crisis' highlighted earlier in this article, are overcome through a 'forgetting' and full immersion in the natural space.

\section{Facilitator for change}

In this final section of the analysis we attempt to build on Brooks, Wallace, and Williams (2006) suggestion that outdoor activities lead to a self - place attachment resulting in greater care for the location where the activity takes place and also offer an account of the potential such engagements have on pro-environmental attitudes 'spilling over' in to the everyday.

After spending years outdoors I have seen a lot, good and bad, I have seen every type of stunning landscape, green and rocky mountains, lakes and rivers, but I have also seen what it means to act irresponsibly and degrade nature... became very culturally and environmentally aware (P 13)

In the above extract the participant talks generally about their experience of nature whilst engaging with outdoor adventure activities. We see nature presented as pristine through the account of the "stunning landscape, green and rocky mountains, lakes and rivers". Such an account draws on a dominant historical 'imagination' of the natural environment as untouched by the unnatural human world opening it up as something for humans to marvel at (Cox, 2013). However, throughout the above extract there is also an educational element brought to the forefront of the account. Through seeing "good and bad" and "what it means to act irresponsibly and degrade nature", for this participant it was direct experience with nature that appears to serve as a source of developing proenvironmental attitudes similar to that found in childhood exposure of nature (Place \& Ewert, 2001). Such a position is further elaborated through reflections of the participants' who have become "very culturally and environmentally aware" as a result of their engagement with outdoor adventure activities.

This understanding of environmental awareness facilitated via engagement with outdoor adventure tourism activities is further expanded in the following quote:

Your awareness becomes more and more with each dive. You see someone doing something forbidden during the dive or just on the beach, I will be the one telling them not to do that ( $P$ 12) 
Here we see again how engagement with outdoor adventure tourism leads to an increased awareness of the human-induced negative environmental impacts. The increased level of participation appears to be central to this participant's experiences and awareness raising. Such an account echos Van Riper et al's (2010) finding that increasing level of participation in outdoor recreation facilitates the development of environmental attitudes and an increased sensitivity towards environmental impacts associated with adventure activities. However, there are also tropes of 'environmental citizenship' (Dobson, 2007) reverberating throughout the extract via the explicit recognition that the individual has shifted their position from a passive observer to an active participant in environmental protection through their suggestion that they will "be the one telling them not to do that". Such 'global citizenship', or "reciprocal obligation" (Foucault, 1990), could usefully be understood through the explicit reconnection of the ecological unconscious to 'Mother Nature' (Davis, 1998) which encourages a caring for the 'Mother' due to the reciprocal interdependence. Similar accounts were found throughout the corpus of data with additional affective, experiential, sensory and emotional connections facilitating this care expressed in the following two quotations:

We don't even pick the flower. When it is easy for you to go there, you don't appreciate it and you dump your rubbish. But when you have to walk for it under the hot sun for 12 hours and carry a heavy backpack, when you go there you understand (P15)

It brought me closer to all those concerns... it was in my face in the forest. Instead of reading about how forests have issues in this country, l experienced it with my own eyes, emotions, feelings, and senses... I am far more intimate with it and it has helped me to better understand ( $P$ 10)

Beyond the immediate connection to nature and subsequent citizenship and care for the environment, Palmberg and Kuru (2000) suggest that outdoor activities have the potential to evoke feelings of anxiety and guilt towards the status of the environment when experiencing environmental degradation in person. They suggest that as a result of this anxiety and guilt, individuals respond/cope by experiencing greater care for the environment and adopting a position of 'guardianship' over the environment. Such understanding is present throughout the extracts presented in this section thus far, however these feelings can spill over in to the everyday attitudes and behaviours of the participants (Palmberg \& Kuru, 2000). Therefore, engagement with outdoor adventure activities could usefully be understood as forms of sustainable tourism, potentially acting as a catalyst for broader pro-environmental behavioural change, and this was certainly the case for the participants in this research. Such a position is succinctly summarised in the following extract:

Now that I have spent years and years at trails where I have seen with my own eyes people throwing trash to the forests or making fires I realized how negative I felt for my own self too. So I understood what it means to recycle and now I literally recycle everything and I try to encourage my house mates too ( $P$ 2)

\section{Discussion and conclusion}

...man [sic] had to regulate his conduct, not simply by virtue of status, privileges, and domestic functions, but also by virtue of a 'relational role'...they show not only that this role was a governmental function of training, education, and guidance, but that it was involved in 
a complex interplay of affective reciprocity and reciprocal dependence (Foucault, 1990, p. 80)

This article sought to contribute to our understanding of sustainable tourism through a focus on outdoor adventure tourism activities. Through the utilisation of contemporary research on outdoor adventure activities as a vehicle of a deeper appreciation of human nature relationships (Brymer \& Gray, 2009), theoretical insights both from eco-psychology (Roszak, 1992) and Foucault's 'technologies of the self' (Foucault, 1988), this article has attempted to contribute to sustainable tourism theory by highlighting the potential sustainability and wellbeing benefits of outdoor adventure tourism. Following on from the contextual and theoretical framing of the article, we introduced the reader to our participants, namely individuals that have engaged with a range of outdoor adventure tourism ventures. The first section of our findings clearly demonstrated that the dominant notions of risk, excitement, thrill or a power to 'overcome' (Buckley, 2006) were clearly central to our participants' understandings of their experience and potential motivations for engagement with outdoor adventure tourism activities.

However, as Foucault comments above, individuals do not/ought not to live and experience their lives in relation to the dominant structures affecting our lives. We ought to also understand and celebrate our 'relational role' in terms of the 'complex interplay of affective reciprocity and reciprocal dependence' because as Foucault noted, it is through these that we can 'cultivate the self as an ethical subject'. Throughout the second and third sections of the analysis we have highlighted elements of the 'affective reciprocity and reciprocal dependence' between our participants and the natural environment and the wellbeing benefits such relationships facilitate. In the second section we utilised insights from eco-psychology to show the ways in which the embodied and sensory experience of outdoor adventure tourism could usefully be understood as a reawakening and appreciation for the unconscious and deeply rooted bonds between the psyche and 'Gaia' (Roszak, 1995). Such an understanding reconnects individuals with nature in a way that enables a deeper appreciation for nature, potentially providing healing for both the individuals wellbeing and the natural environment (Davis, 1998), offering potential avenues for sustainable tourism practice. Further, in light of the mental health 'crisis' highlighted in the introduction to this article, we tentatively suggest that outdoor adventure tourism offers mental health benefits and some form of distress alleviation through active engagement with the natural environment.

The final section of the analysis sought to build on this understanding of the 'affective reciprocity and reciprocal dependence' between the participants and the natural environment by exploring the ways in which their experiences encouraged a sense of citizenship (Dobson, 2007) and guardianship (Palmberg \& Kuru, 2000) over the natural space. By understanding the experiences as a reconnection between the psyche and nature, this section of the analysis demonstrated the ways in which individuals feel an affinity to, and sense of protection for, the natural environment as it is understood as intrinsically linked to the self. Further, this care and protection was expanded not just to the immediate present, but also to the everyday awareness and practices of the participants. In summary then, the findings in this article suggest that we should be very cautious about discouraging outdoor adventure tourism due to its environmentally 'destructive' qualities (Buckley, 2005). Rather, we hope to have demonstrated that it might prove fruitful to promote and encourage such activities for the psychological wellbeing and environmental attitude effects. Such a proposition appears fruitful for future investigations in sustainable tourism practice, theory and research.

Of course, this research is not without its limitations and whilst we have attempted to convince the reader of the positive elements of engaging with outdoor adventure tourism in relation to environmental sustainability and individual wellbeing, the evidence presented here is not sufficient 
to make such a definitive case. Therefore we would encourage further research integrating ecopsychology in to sustainable tourism research to develop this area on both a theoretical and empirical level. It would also prove potentially fruitful to develop large scale quantitative studies to measure the wellbeing effect before, during and after engagement with the forms of tourism activities. Finally, future research might also consider the impact childhood experiences with nature (including urban or rural living) on their experience with outdoor adventure tourism as there is research to suggest those with a lack of engagement at a young age often view nature as a scary space (Louv, 2005) which could result in counterproductive outcomes for the individual.

\section{References}

Abbas, K., Christie, I., Demassieux, F., Hayward, B., Jackson, T., \& Pierre, F. (2013). Sustainable consumption and lifestyles? Children and youth in cities. In ISSC/UNESCO (Ed.), World Science Report 2013: Changing Global Environments (pp. 357-364): OECD Publishing and Unesco Publishing.

Adams, M., \& Jordan, M. (2016). Growing Together: Nature Connectedness, Belonging and Social Identity in a Mental Health Ecotherapy Programme. In M. Jordan \& J. Hinds (Eds.), Ecotherapy: Theory, Research and Practice. Basingstoke: Palgrave Macmillan.

Anderson, J. (2009). Transient convergence and relational sensibility: Beyond the modern constitution of nature. Emotions, Space and Society, 2, 120-127.

Barber, N. A. (2014). Profiling the Potential "Green" Hotel Guest: Who Are They and What Do They Want? Journal of Hospitality and Tourism Research, 38(3), 361-387.

Barton, J., Hine, R., \& Pretty, J. (2009). The health benefits of walking in greenspaces of high natural and heritage value. Journal of Integrative Environmental Sciences, 6(4), 261-278.

Beedie, P., \& Hudson, S. (2003). Emergence of Mountain-Based Adventure Tourism. Annals of Tourism Research, 30(3), 625-643.

Bowker, J. M., \& English, D. B. (2002). Mountain biking at Tsali: An assessment of users, preferences, conflicts, and management alternatives. Gen. Tech. Rep. SRS-59. Asheville, NC: US Department of Agriculture, Forest Service, Southern Research Station. 28 p., 59.

Braun, V., \& Clarke, V. (2006). Using thematic analysis in psychology. Qualitative Research in Psychology, 3(2), 77-101.

Bringslimark, T., Hartig, T., \& Patil, G. G. (2009). The psychological benefits of indoor plants: A critical review of the experimental literature. Journal of Environmental Psychology, 29(4), 422-433.

Brooks, J. J., Wallace, G. N., \& Williams, D. R. (2006). Place as relationship partner: An alternative metaphor for understanding the quality of visitor experience in a backcountry setting. Leisure Sciences, 28(4), 331-349. 
Brown, A. K., Liu-Ambrose, T., Tate, R., \& Lord, S. R. (2009). The effect of group-based exercise on cognitive performance and mood in seniors residing in intermediate care and self-care retirement facilities: a randomised controlled trial. British journal of sports medicine, 43(8), 608-614.

Bryman, A. (2004). Social Research Methods (2nd ed.). Oxford: Oxford University Press.

Brymer, E., Downey, G., \& Gray, T. (2009). Extreme Sports as a Precursor to Environmental Sustainability. Journal of Sport \& Tourism, 14(2-3), 193-204.

Brymer, E., \& Gray, T. (2009). Dancing with nature: Rhythm and harmony in extreme sport participation. Journal of Adventure Education \& Outdoor Learning, 9(2), 135-149.

Buckley, R. (2002). Surf Tourism and Sustainable Development in Indo-Pacific Islands. I. The Industry and the Islands. Journal of Sustainable Tourism, 10(5), 405-424.

Buckley, R. (2005). Social Trends and Ecotourism: Adventure Recreation and Amenity Migration. Journal of Ecotourism, 4(1), 56-61.

Buckley, R. (2006). Adventure tourism. Wallingford: Cabi.

Buckley, R. (2012). Rush as a key motivation in skilled adventure tourism: Resolving the risk recreation paradox. Tourism Management, 33(4), 961-970.

Capaldi, C. A., Passmore, H.-A., Nisbet, E. K., Zelenski, J. M., \& Dopko, R. L. (2015). Flourishing in nature: A review of the benefits of connecting with nature and its application as a wellbeing intervention. International Journal of Wellbeing, 5(4).

Cessford, G. R. (1995). Off-road mountain biking: A profile of participants and their recreation setting and experience preferences: Department of Conservation Wellington,, New Zealand.

Clift, S., Hancox, G., Morrison, I., Hess, B., Kreutz, G., \& Stewart, D. (2010). Choral singing and psychological wellbeing: Quantitative and qualitative findings from English choirs in a crossnational survey. Journal of Applied Arts and Health, 1(1), 19-34.

Cooper, G., Green, N., Burningham, K., Evans, K., \& Jackson, T. (2012). Unravelling the Threads: Discourses of Sustainability and Consumption in an Online Forum. Environmental Communication, 6(1), 101-118.

Cox, R. (2013). Environmental Communication and the Public Sphere (3rd ed.). London: Sage.

Cromby, J., Harper, D., \& Reavey, P. (2013). Psychology, mental health and distress. Basingstoke: Palgrave Macmillan.

Csikszentmihalyi, M., \& Csikszentmihalyi, I. S. (1992). Optimal experience: Psychological studies of flow in consciousness: Cambridge university press.

Darnton, A., Verplanken, B., White, P., \& Whitmarsh, L. (2011). Habits, Routines and Sustainable Lifestyles: A summary report to the Department for Environment, Food and Rural Affairs. Retrieved from London:

Davis, J. (1998). The transpersonal dimensions of ecopsychology: Nature, nonduality, and spiritual practice. The Humanistic Psychologist, 26(1-3), 69.

Davis, J., Green, J. D., \& Reed, A. (2009). Interdependence with the environment: Commitment, interconnectedness, and environmental behavior. Journal of Environmental Psychology, 29(2), 173-180.

Dobson, A. (2007). Environmental citizenship: towards sustainable development. Sustainable Development, 15(5), 276-285.

Dolnicar, S. (2010). Identifying tourists with smaller environmental footprints. Journal of Sustainable Tourism, 18, 717-734.

Dolnicar, S., Yanamandram, V., \& Cliff, K. (2012). The contribution of vacations to quality of life. Annals of Tourism Research, 39(1), 59-83.

Evans, D., \& Jackson, T. (2007). Towards a Sociology of Sustainable Lifestyles. Retrieved from RESOLVE Working Paper Series 03-07:

Ewert, A. W., \& Hollenhorst, S. J. (1989). Testing the adventure model: Empirical support for a model of risk recreation participation. Journal of Leisure Research, 21(2), 124-139. 
Filep, S. (2012). Positive psychology and tourism Handbook of tourism and quality-of-life research (pp. 31-50): Springer.

Fisher, A. (2002). Radical Ecopsychology: Psychology in the Service of Life. New York: State University of New York Press.

Foucault, M. (1988). Technologies of The Self. In L. H. Martin, H. Gutman, \& P. Hutton (Eds.), Technologies of The Self: A Seminar With Michel Foucault. Amherst: University of Massachusetts Press.

Foucault, M. (1990). The Care of Self: The History of Sexuality, Volume 3. (R. Hurley, Trans). London: Penguin.

Freudenburg, W. R., \& Muselli, V. (2013). Reexamining Climate Change Debates: Scientific Disagreement or Scientific Certainty Argumentation Methods (SCAMs)? American Behavioral Scientist, 57, 777-795.

Gili, M., Roca, M., Basu, S., McKee, M., \& Stuckler, D. (2012). The mental health risks of economic crisis in Spain: evidence from primary care centres, 2006 and 2010. The European Journal of Public Health, 23(1), 103-108.

Gkargkavouzi, A., Paraskevopoulos, S., \& Matsiori, S. (2018). Assessing the structure and correlations of connectedness to nature, environmental concerns and environmental behavior in a Greek context. Current Psychology, 1-18.

Goeft, U., \& Alder, J. (2001). Sustainable mountain biking: a case study from the southwest of Western Australia. Journal of Sustainable Tourism, 9(3), 193-211.

Gosling, E., \& Williams, K. (2010). Connectedness to nature, place attachment and conservation behaviour: Testing connectedness theory among farmers. Journal of Environmental Psychology, 30(3), 298-304.

Goudie, A. S. (2019). Human impact on the natural environment (8th ed.). Chichester: John Wiley \& Sons.

Greenway, R. (1995). The wilderness effect and ecopsychology. In T. Roszak, M. E. Gomes, \& A. D. Kanner (Eds.), Ecopsychology: Restoring the earth, healing the mind (pp. 122-135). San Francisco: Sierra Club Books.

Gunnell, D., Kidger, J., \& Elvidge, H. (2018). Adolescent mental health in crisis. British Medical Journal, 361(k2608). doi:https://doi.org/10.1136/bmj.k2608

Gyimóthya, S., \& Mykletunb, R. J. (2004). Play in adventure tourism: The Case of Arctic Trekking. Annals of Tourism Research, 31(4), 855-878.

Hall, C. M. (1992). Review: adventure, sport and health tourism. In H. C.M \& W. B (Eds.), Special interest tourism. (pp. 141-158). London: Belhaven Press.

Han, K.-T. (2009). Influence of limitedly visible leafy indoor plants on the psychology, behavior, and health of students at a junior high school in Taiwan. Environment and Behavior, 41(5), 658692.

Hanna, P. (2013). Foucauldian Discourse Analysis in Psychology: Reflecting on a Hybrid Reading of Foucault When Researching "Ethical Subjects". Qualitative Research in Psychology, Online, 139.

Hanna, P. (2013). Reconceptualizing subjectivity in critical social psychology: Turning to Foucault. Theory \& Psychology, 23(5), 657-674.

Hanna, P., Johnson, K., Stenner, P., \& Adams, M. (2014). Foucault, sustainable tourism, and relationships with the environment (human and nonhuman). GeoJournal, Online.

Hay, B. (2013). From Leisure to Pleasure: Societal Trends and Their Impact on Possible Future Scenarios for UK in 2050. Paper presented at the Active Countryside Tourism, Leeds.

Heyes, C. (2007). Self-Transformations: Foucault, Ethics, and Normalized Bodies. Oxford: Oxford University Press.

Humberstone, B. (2009). Inside/outside the Western 'Bubble': The nexus of adventure, adventure sports and perceptions of risk in UK and Mauritius. In J. Ormrod \& B. Wheaton (Eds.), On the 
Edge: Leisure, Consumption and the Representation of Adventure Sports. University of Michigan: Leisure Studies Association.

Humberstone, B. (2013). Adventurous activities, embodiment and nature: spiritual, sensual and sustainable? Embodying environmental justice. Motriz: Revista de Educação Física, 19(3), 565-571.

IPCC. (2013). Summary for Policymakers. In T. F. Stocker, D. Qin, G.-K. Plattner, M. Tignor, S. K. Allen, J. Boschung, A. Nauels, Y. Xia, V. Bex, \& P. M. Midgley (Eds.), Climate Change 2013: The Physical Science Basis. Contribution of Working Group I to the Fifth Assessment Report of the Intergovernmental Panel on Climate Change. Cambridge: Cambridge University Press.

IPCC. (2014). Climate Change 2014: Synthesis Report. Retrieved from http://www.ipcc.ch/

Johansson, M., Hartig, T., \& Staats, H. (2011). Psychological benefits of walking: Moderation by company and outdoor environment. Applied Psychology: Health and Well-Being, 3(3), 261280.

Klaniecki, K., Leventon, J., \& Abson, D. J. (2018). Human-nature connectedness as a 'treatment'for pro-environmental behavior: making the case for spatial considerations. Sustainability Science, 13(5), 1375-1388.

Klaus, P., \& Maklan, S. (2011). Bridging the gap for destination extreme sports: A model of sports tourism customer experience. Journal of Marketing Management, 27(13-14), 1341-1365.

Latour, B. (2004). Politics of Nature. How to Bring the Sciences into Democracy. London: Harvard University Press.

Louv, R. (2005). Last Child in the Woods: SAving our Children from Nature-Deficit Disorder. New York: Workman Publishing.

Lund, K. A. (2013). Experiencing nature in nature-based tourism. Tourist studies, 13(2), 156-171.

Macpherson, H., Hart, A., \& Heaver, B. (2015). Building resilience through group visual arts activities: Findings from a scoping study with young people who experience mental health complexities and/or learning difficulties. Journal of Social Work, 1468017315581772.

Mannion, A. (2014). Global environmental change: a natural and cultural environmental history (2nd ed.). London: Routledge.

Martyn, P., \& Brymer, E. (2016). The relationship between nature relatedness and anxiety. Journal of health psychology, 21(7), 1436-1445.

McCabe, S. (2009). Who needs a holiday? Evaluating social tourism. Annals of Tourism Research, 36(4), 667-688.

McCabe, S., \& Johnson, S. (2013). The happiness factor in tourism: Subjective well-being and social tourism. Annals of Tourism Research, 41, 42-65.

McManus, S., Bebbington, P., Jenkins, R., \& Brugha, T. (2016). Mental health and wellbeing in England: Adult Psychiatric Morbidity Survey 2014. Leeds: NHS Digital, 39-40.

McPherson Frantz, C., \& Mayer, S. F. (2014). The importance of connection to nature in assessing environmental education programs. Studies in Educational Evaluation, 41, 85-89.

Morgan, N., Pritchard, A., \& Sedgley, D. (2015). Social tourism and well-being in later life. Annals of Tourism Research, 52, 1-15.

Nisbet, E. K., Zelenski, J. M., \& Murphy, S. (2009). The Nature Relatedness Scale Linking Individuals' Connection With Nature to Environmental Concern and Behavior. Environment and Behaviour, 41(5), 715-740.

Nyström, M., Folke, C., \& Moberg, F. (2000). Coral reef disturbance and resilience in a humandominated environment. Trends in Ecology \& Evolution, 15(10), 413-417.

OECD. (2019). OECD Better Life Index. Retrieved from http://www.oecdbetterlifeindex.org/\#/11111111111

Olivier, S. (2006). Moral Dilemmas of Participation in Dangerous Leisure Activities. Leisure Studies, 25(1), 95-109.

Page, S. J., Bentley, T. A., \& Walker, L. (2005). Scoping the nature and extent of adventure tourism operations in Scotland: how safe are they? Tourism Management, 26, 381-397. 
Palmberg, I. E., \& Kuru, J. (2000). Outdoor Activities as a Basis for Environmental Responsibility. The Journal of Environmental Education, 31(4), 32-36.

Palmer, C. (2004). Death, danger and the selling of risk in adventure sports. In B. Wheaton (Ed.), Understanding Lifestyle Sports: consumption, identity and difference. London: Routledge.

Panzone, L., Hilton, D., Sale, L., \& Cohen, D. (2016). Socio-demographics, implicit attitudes, explicit attitudes, and sustainable consumption in supermarket shopping. Journal of Economic Psychology, 55, 77-95.

Pearce, P. L., \& Packer, J. (2013). Minds on the move: New links from psychology to tourism. Annals of Tourism Research, 40, 386-411.

Pennington-Gray, L. A., \& Kerstetter, D. L. (2002). Testing a constraints model within the context of nature-based tourism. Journal of Travel Research, 40(4), 416-423.

Petrick, J. F., \& Huether, D. (2013). Is travel better than chocolate and wine? The benefits of travel: A special series. Journal of Travel Research, 52(6), 705-708.

Place, G., \& Ewert, A. (2001). Impact of Early-life Outdoor Experiences on an Individual's Environmental Attitudes. Leisure Sciences, 27(3), 225-239.

Pomfret, G., \& Bramwell, B. (2014). The characteristics and motivational decisions of outdoor adventure tourists: a review and analysis. Current Issues in Tourism, Online.

Pratt, M. L. (2007). Imperial eyes: Travel writing and transculturation (2 ed.). London: Routledge.

Quastel, N. (2008). Ethical Consumption, Consumer Self-Governance, and the Later Foucault. Dialogue, 47, 25-52.

Roberts, S., \& Bradley, A. J. (2011). Horticultural therapy for schizophrenia. Cochrane Database of Systematic Reviews(11).

Rosa, C. D., Profice, C., \& Collado, S. (2018). Nature Experiences and Adults' Self-Reported Proenvironmental Behaviors: The Role of Connectedness to Nature and Childhood Nature Experiences. Frontiers in psychology, 9, 1055.

Roszak, T. (1992). Voice of the Earth: an exploration of ecopsychology. Grand Rapids: Phanes Press Inc.

Roszak, T. (1995). Where Psyche meets Gaia. In T. Roszak, M. E. Gomes, \& A. D. Kanner (Eds.), Ecopsychology: Restoring the earth, healing the mind (pp. 1-17). San Francisco: Sierra Club Books.

Russell, R., Guerry, A. D., Balvanera, P., Gould, R. K., Basurto, X., Chan, K. M., . . Tam, J. (2013). Humans and nature: how knowing and experiencing nature affect well-being. Annual Review of Environment and Resources, 38, 473-502.

Sedgley, D., Pritchard, A., Morgan, N., \& Hanna, P. (2017). Tourism and autism: Journeys of mixed emotions. Annals of Tourism Research, 66, 14-25.

Self, D. R., Henry, E. D., Findley, C. S., \& Reilly, E. (2007). Thrill seeking: The type T personality and extreme sports. International Journal of Sport Management and Marketing Science, 2(1-2), 175-190.

Shephard, G., \& Evans, S. (2005). Adventure tourism - hard decisions, soft options and home for tea: adventure on the hoof. In M. Novelli (Ed.), Niche tourism: contemporary issues, trends and cases (pp. 201-209). Oxford: Butterworth-Heinemann Ltd.

Shove, E. (2010). Beyond the ABC: Climate Change Policy and Theories of Social Change. Environment and Planning A, 42(6), 1273-1285.

Smith, J., \& Osborn, M. (2008). Interpretative Phenomenological Analysis. In J. Smith (Ed.), Qualitative Psychology: A Practical Guide to Research Methods (2nd ed.). London: Sage.

Stranger, M. (2010). Surface and substructure: beneath surfing's commodified surface. Sport in Society: Cultures, Commerce, Media, Politics, 13(7-8), 1117-1134.

Swarbrooke, J., Beard, C., Leckie, S., \& Pomfret, G. (2003). Adventure tourism. The new frontier. Oxford: Butterworth-Heinemann Ltd.

Thorpe, H., \& Rinehart, R. (2010). Alternative sport and affect: non-representational theory examined. Sport in Society: Cultures, Commerce, Media, Politics, 13(7-8), 1268-1291. 
Thorpe, K. E., Florence, C. S., \& Joski, P. (2004). Which Medical Conditions Account For The Rise In Health Care Spending? The fifteen most costly medical conditions accounted for half of the overall growth in health care spending between 1987 and 2000. Health affairs, 23(Suppl1), W4-437-W434-445.

Thrift, N. (2008). Non-representational theory: Space, politics, affect: Routledge.

Tsaur, S.-H., Lin, W.-R., \& Liu, J. S. (2013). Sources of challenge for adventure tourists: Scale development and validation. Tourism Management, 38, 85-93.

Ulrich, R. (1984). View through a window may influence recovery. Science, 224(4647), 224-225.

UN. (2019). Goal 3: Ensure healthy lives and promote well-being for all at all ages. Retrieved from https://www.un.org/sustainabledevelopment/health/

Van Riper, C. J., Manning, R. E., \& Reigner, N. (2010). Perceived Impacts of Outdoor Recreation on the Summit of Cascade Mountain, New York. Adirondack Journal of Enviornmental Studies, 16.

Walker, C., Hart, A., \& Hanna, P. (2017). Building a new community psychology of mental health: spaces, places, people and activities. Basingstoke: Palgrave Mcmillian.

WCED. (1987). Our Common Future, The World Commission on Environment and Development.

Whatmore, S. (2002). Hybrid Geographies: natures cultures spaces. London: Sage.

Whiteford, H. A., Degenhardt, L., Rehm, J., Baxter, A. J., Ferrari, A. J., Erskine, H. E., . . Johns, N. (2013). Global burden of disease attributable to mental and substance use disorders: findings from the Global Burden of Disease Study 2010. The Lancet, 382(9904), 1575-1586.

Williams, P., \& Soutar, G. (2005). Close to the "edge": Critical issues for adventure tourism operators. Asia Pacific Journal of Tourism Research, 10(3), 247-261.

Williams, S. (2003). Tourism and recreation. Harlow: Pearson Education.

Yates, S., \& Hiles, D. (2010). Towards a 'Critical Ontology of Ourselves'?: Foucault, Subjectivity and Discourse Analysis. Theory \& Psychology, 20, 52-75.

Zelenski, J. M., \& Nisbet, E. K. (2014). Happiness and feeling connected: The distinct role of nature relatedness. Environment and Behavior, 46(1), 3-23.

Zhang, J. W., Howell, R. T., \& Iyer, R. (2014). Engagement with natural beauty moderates the positive relation between connectedness with nature and psychological well-being. Journal of Environmental Psychology, 38, 55-63. 